\title{
Carbon Mineralization in Soils Irrigated with Treated Swine Wastewater
}

\author{
Sarah Mello Leite Moretti ${ }^{1}$, Edna Ivani Bertoncini ${ }^{2} \&$ Cassio Hamilton Abreu-Junior ${ }^{1}$ \\ ${ }^{1}$ University of São Paulo, Center for Nuclear Energy in Agriculture, São Paulo, Brazil \\ ${ }^{2}$ São Paulo's Agency for Agribusiness Technology, Secretariat of Agriculture and Food Supply of São Paulo, São \\ Paulo, Brazil \\ Correspondence: Sarah Mello Leite Moretti, Center for Nuclear Energy in Agriculture, University of São Paulo, \\ Av. Centenário, 303, Piracicaba, São Paulo, SP, Brazil. Tel: 55-19-3421-1478. E-mail: sarahmello@hotmail.com
}

Received: December 7, 2016

Accepted: January 9, 2017

Online Published: February 15, 2017

doi:10.5539/jas.v9n3p19

URL: http://dx.doi.org/10.5539/jas.v9n3p19

\begin{abstract}
Treated swine wastewater agricultural use can promote environmental and agronomical improvements, however, the inappropiate management of this organic load added on soil can cause unbalances in soil fertility and in availability of nutrients and/or contaminants. Thus, this study aim was evaluate the organic matter biodegradation of treated swine wastewater (WB) and diluted swine wastewater (WBD) applied in Oxisol clayey texture (CS) and in Ultisol (SS) with medium-sandy texture. The treatments studied were: R1 - CS control; R2 irrigation with WB on CS; R3 - irrigation with WBD on CS; R4 - SS control; R5 - irrigation with WBD on SS; R6 - irrigation with WBD on SS. Three applications were done in flasks containing $500 \mathrm{~g}$ of soils sampled from depth of $0-20 \mathrm{~cm}$, the $\mathrm{C}-\mathrm{CO}_{2}$ evolutions and degradation fractions were quantified after each application. The results obtained were adjusted to first-order chemical kinetics model. More than half organic matter was biodegraded between 4 and 10 days of incubation, when higher WB amount was applied $(33.3 \mathrm{~mm})$. Sucessive WBD use caused degradation of organic matter remaning of previous application. Higher $\mathrm{CO}_{2}$ evolutions were obtained for Oxisol treatments due to higher carbon contents of this soil. SW use caused depletion of Ultisol native organic matter. However, the WB use in Oxisol provided accumulation of organic matter. Soon, the respirometry test evidenced the importance of evaluate the soil depuration capacity before agricultural use, since that this process can affect the contents of organic matter native of these soils and the availabity of nutrient/contaminant for soil-water-plant system.
\end{abstract}

Keywords: organic matter, respirometry, swine waste

\section{Introduction}

The swine production has faced difficulties in treatment and destination of waste large volum generated by this activity. In Brazil, according to Takitane et al. (2012) are generated more than 100 milions cubic meters by year of swine waste from cleaning of the bays through washing with hose, which is a hygienic and sanitary management adopted by Brazilian pig farms. In comparison to other agricultural activities, the swine production is considered the most polluting agricultural activity of surface water and groundwater (Novaes, 2001). For many years, untreated swine wastes were applied in agricultural soils next to swine farms, causing the contamination of these areas. However, there is little information about the contamination level of these areas as well as what would be the waste treatment system to be adapted to each reality, for the sustainable use of these wastes in agricultural soils (Bertoncini, 2016).

Despite its pollutant potential, the treated swine wastewater use can be a sustanaible agricultural destination, promoting rational use of water and economy in chemical fertilizer, besides using the soil as a purifier of the organic load present in swine waste. For this, the waste previous treatment is need, in order to reduce contaminants and, mainly, the initial organic matter content that is around to $25000 \mathrm{mg} \mathrm{L}^{-1}$ (Moral el al., 2008), fifty times higher than the organic matter content present in sanitary sewage, around of $500 \mathrm{mg} \mathrm{L}^{-1}$ (Duda \& Oliveira, 2011).

Soon, the organic waste application in agricultural soils, as swine wastewater, can cause changes in the soil organic matter dynamics (Soares et al., 2010), as well as in the chemical and physical characterstics of soil. The 
degradation process velocity of organic material present in organic wastes affects the availability of nutrients and other elements for soil-water-plant system, once that these elements can be linked to organic matter. In the same way, the mineralogical characteristics of soil affects the availability of nutrients and other elements in soil solution, because interactions between soil minerals and organic matter can occur, affecting the degradation of organic material added and releasing of these elements (Bayer et al., 2002; Bertoncini et al., 2008). Thus, these processes should be known before organic waste application in agricultural soils because they can affect the nutrients cycling and, the inappropriate use of these organic wastes can cause unbalance in soil fertility (Ceretta et al., 2010).

Studies performed by Lourenzi (2014) showed an increase in carbon and organic matter contents of Ultisol, after succesive application of differents doses of swine wastewater, for both soils depths studied. However, for an Oxisol, the authors observed increases in carbon and organic matter content only on soil superficial depth. This fact occurred due to mineralogical differences between the two soils studied, the Ultisol presented lower clay content compared to Oxisol, promoting the percolation of particulate organic matter to the subsurface horizon of Ultisol. Besides this, the higher content of clay and $\mathrm{Fe}$ and $\mathrm{Al}$ oxides present in the Oxisol protected the organic matter from its rapid decay, and this is very common in soils under tropical conditions (Bayer et al., 2002), retaining the organic matter on superficial horizon.

In turn, Agne and Klein (2014) did not find significant changes in organic matter content of an Oxisol amended with swine wastewater for 5 years. However, the organic matter content was higher in the superficial horizon, indicating its accumulation on superficial horizon. This absence of effect about soil organic matter content could be due to low dry matter content of swine wastewater applied (1.72\%) and to high soil fertility.

Organic matter degradation process and its effects about the soil organic matter content are influenced by several factors as: temperature, humidity, organic material characteristics, application frequency, and other factors. In accordance to Dinel and Gregorich (1995), the organic material present in swine wastes contains polysaccharides, lipids, proteins and others aromatic compounds, which have different degration rates on soil. After swine wastewater treatment, the biodegrable organic fraction is reduced, increasing the recalcitrant carbon concentration (Soares et al., 2010) and reducing the degradability of organic material. Reduction of the waste organic load and the concentration of nutrients and/or contaminants in the treated effluent would depend of the type of treatment to which the raw waste will be submitted in an effluent treatment plant, such as anaerobic or aerobic biodigestion.

Similarly, soils with high contents of iron and aluminum oxids can present high organic matter contents due to organomineral complex formation, nevertheless, in sandy soils the organic matter is easily degraded (Lourenzi, 2014; Bertoncini et al., 2008; Inda Junior et al., 2007). Therefore, the organic waste degradation kinetics on soil should be evaluated, because the agricultural use of some wastes can promote the degradation of native soil organic matter. In this process, called priming effect, the soil microbiota mineralizes both organic matter added by waste and soil native organic matter (Fontaine, Mariotti, \& Abbadie, 2003). This effect is harmful for tropical soils that present low organic matter contents.

Thus, this study was conducted considering the needs to propose sustainable alternatives for the use of treated swine wastewater in agricultural soils, and the lack of studies to evaluate the remaining organic matter degradation, after application on soil of swine wastewater treated in biodigester and diluted swine wastewater, simulating the effluents successive applications in clayey and sandy soils. In order to verify the organic matter depuration capacity by these soils, since, this fact could affect the nutrients/contaminants availability to the soil-water-plant system, as well as, to affect the soils characteristics.

\section{Method}

The swine effluents used in this study were obtained of a pilot treatment system installed in a swine farm with

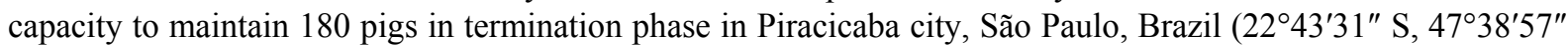
$\mathrm{W}$; altitude de $547 \mathrm{~m}$ ). The swine waste (SW) was sieved in a rotary sieve with mesh diameter equal to $0.65 \mathrm{~mm}$ and capacity for $10 \mathrm{~m}^{3} \mathrm{~h}^{-1}$ of SW, for separate the suspended solids, amount around $6 \%$. The liquid phase was sent to anaerobic biodigestor, with a diameter of $3.0 \mathrm{~m}, 12 \mathrm{~m}$ in length, volum of $60 \mathrm{~m}^{3}$ for effluent and $30 \mathrm{~m}^{3}$ for biogas, and hidraulic retention time minimum of 30 days.

The swine wastewater treated in biodigester (WB) was dilluted (WBD), in order to simulate the effluent characterization from other treatments phases as aerobic digeston, physical-chemical process, with lower organic matter content and nutrients. The effluents used in this study were sampled and characterized in accordance to Eaton et al. (2005) for the following parameters: $\mathrm{pH}$, electrical conductivity (EC), total solids (TS), fixed solids 
(FS), volatile solids (VS), biochemical oxygen demand (BOD) for the five-day period at $20^{\circ} \mathrm{C}$, chemical oxygen demand (COD), contents of C, N, P, K, Ca, Mg, Mn, Fe, Cu and Zn.

The effects of successive applications of WB and WBD about organic matter degradation in soils of different textural class were evaluated by respirometry test in accordance to modified Bartha respirometric method (Environmental Company of São Paulo State [CETESB], 1999). This method is based on reaction of a solution of sodium hydroxid $(\mathrm{NaOH})$ with carbon dioxide generated during the microbial decomposition process of organic material present on swine effluents applied in soils.

Soil samples were collected from 0-20 depth layer from areas of clayey Oxisol (CS) and Ultisol (SS) with medium-sandy texture, according to American Soil Taxonomy (United States Departament of Agriculture [USDA], 2006). So, $500 \mathrm{~g}$ of soils samples were added to respirometric flasks, followed by addition of each amount of effluents studied. Flasks with $50 \mathrm{ml}$ of $0.5 \mathrm{~mol} \mathrm{~L}^{-1} \mathrm{NaOH}$ solution were added to respirometric flasks and, then, these respirometric flasks were incubated to $\pm 25^{\circ} \mathrm{C}$, in accordance to CETESB (1999).

This test was conducted with three replicates and the following treatments were evaluated: R1 - CS control; R2 - irrigation with WB on CS; R3 - irrigation with WBD on CS; R4 - SS control; R5 - irrigation with WBD on SS; R6 - irrigation with WBD on SS. Tree successive applications were performed, the first application was done only with WB on treatments R2, R3, R5 e R6, with the dose corresponding to the incorporation of $133 \mathrm{~kg}$ $\mathrm{ha}^{-1}$ of nitrogen, in order to simulate an effluent application for supply the initial nitrogen requirement of the maize crop, for example, that is more common crop in swine farms, since the grains are used to make the animal rations.

Initially, $33.3 \mathrm{~mm}$ of $\mathrm{WB}$ were applied in $\mathrm{R} 2, \mathrm{R} 3$, $\mathrm{R} 5$, and $\mathrm{R} 6$. The $\mathrm{CO}_{2}$ released from the decomposition processes of the effluents organic load in the soils was quantified by daily meansuring of the $\mathrm{NaOH}$ electrical conductivity (EC) according Rodella and Saboya (1999).

When there was the EC estabilization in three consecutive determinations, $8.3 \mathrm{~mm}$ of WB (R2 and R5) and WBD (R3 and R6) were re-applied to the soils simulating a second irrigation, and the decomposition process of this organic load was followed until stabilization of the EC measurements. A final application of effluents was equal to $33.3 \mathrm{~mm}$ of WB (R2 and R5) and WBD (R3 and R6), simulating four successive applications of $8.3 \mathrm{~mm}$ of effluents, a higher irrigation frequency as it is performed in drought periods. During the experiment the field capacity of soils was maintained around of $80 \%$ in all treatments.

In the end of each application, the results of $\mathrm{C}_{-} \mathrm{CO}_{2}$ released (C-released) during the incubation time were adjusted to first-order kinetics equation (Lathan, 1974), as discribed in equation 1, determining the parameters: degradation process velocity $(k)$, amount of potentially degraded carbon $\left(C_{0}\right)$, half-life time $\left(T_{1 / 2}\right)$ of organic matter, for each treatment.

$$
\text { C-released }=C_{0} \cdot\left(1-e^{-k t}\right)
$$

Where,

C-released $=$ carbon amount released $\left(\mathrm{mg} \mathrm{kg}^{-1}\right)$ in $\mathrm{CO}_{2}$ form, during the test; $C_{0}=$ carbon potentially degradable and released in $\mathrm{CO}_{2}$ form, during the test; $k=$ organic carbon degradation velocity constant $\left(\right.$ day $\left.^{-1}\right) ; t=$ time in days.

The results were submitted to analysis of variance (ANOVA) and Tukey test to probability equal $95 \%$, using $\mathrm{R}$ software (version 2.15.3) (Venables \& Smith, 2013).

\section{Results and Discussion}

\subsection{Swine Wastewater Characterization}

Table 1 shows the swine waste characterization (SW) sampled before treatment, characterizations of swine wastewater treated in biodigestor (WB) and diluted swine wastewater (WBD) sampled during conduction of biodegradation test. There were reductions in values of BOD, COD, TS, VS, FS, contents of $\mathrm{P}, \mathrm{Ca}, \mathrm{Fe}, \mathrm{Mn}, \mathrm{Cu}$ and $\mathrm{Zn}$.

For $\mathrm{BOD}$, there was a reduction equal $90 \%$ for $\mathrm{WB}$ and $\mathrm{WBD}$ in comparison to $\mathrm{WB}$, this value is higher than $80 \%$ that is the value established by legislation of São Paulo State (São Paulo, 1976) which provides standards for effluent releases into water bodies, after wastewater treatment. Vivan et al. (2010) after swine wastewater treatment observed similar reduction, equal to $90 \%$. This occurred as function of high degradability of organic matter present in swine waste, this fact was confirmed by reductions higher than $90 \%$ obtained for the SV of WB and WBD in comparison to SW, and reductions in C/N ratio that was higher than $70 \%$ for WB and WBD when compared to $\mathrm{SW} \mathrm{C} / \mathrm{N}$ ratio, that was equal to $32: 1$. 
For WB and WBD, the contents of $\mathrm{P}$ and $\mathrm{Ca}$ were reduced after treatment. For $\mathrm{P}$ contents, this reduction was higher than $90 \%$, and for Ca contents was equal to $90 \%$. Vivan et al. (2010) observed a reduction equal to $98 \%$ in contents of $\mathrm{P}$ and $\mathrm{Ca}$, the authors attributed this to probable precipitation of these elements as calcium phosphate, which remain in sludge of biodigestor. Duda and Oliveira (2011) assessed a treatment system consisting of reactors UASB and biologic filter with support material formed by bamboo rings, and the authors observed minerals of $\mathrm{P}, \mathrm{Mg}$, and $\mathrm{Ca}$ adhered to the support material.

For $\mathrm{Fe}$ and $\mathrm{Mn}$ there were reductions equals to $80 \%$ in comparison to contents present in WB. For $\mathrm{Cu}$ and $\mathrm{Zn}$ these reductions were higher and equals to $90 \%$ compared to initials values. In studies performed by Pereira (2006), Amaral, Kunz and Steinmetz (2014), with treatment of SW in anaerobic systems, found similar reductions around of 70 and $90 \%$. Accordig to Amaral et al. (2014) reductions in contents of $\mathrm{Cu}$ and $\mathrm{Zn}$ were due to formations of chemical links with organic matter and sulfides.

There were no changes in contents of $\mathrm{N}, \mathrm{Na}$, and $\mathrm{K}$ present in $\mathrm{WB}$, and these contents in WBD changed when comparade to SW, due to dilution done (1:50, v:v).

Table 1. Physico-chemical characterization of swine waste (SW), swine wastewater treated in a biodigester (WB) and of diluted swine wastewater (WBD) (1:50, v:v) used in each one of tree applications studied on respirometry test

\begin{tabular}{|c|c|c|c|c|c|c|c|}
\hline \multirow{2}{*}{ Parameters } & \multirow{2}{*}{ SW } & \multicolumn{2}{|c|}{$1^{\text {st }}$ application } & \multicolumn{2}{|c|}{$2^{\text {nd }}$ application } & \multicolumn{2}{|c|}{$3^{\text {rd }}$ application } \\
\hline & & WB & WBD & WB & WBD & WB & WBD \\
\hline$p H$ & 5.9 & 7.8 & 8.7 & 7.7 & 8.3 & 8.2 & 8.1 \\
\hline$E C$ & $7.2 \mathrm{~ms} \mathrm{~cm}^{-1}$ & $23.3 \mathrm{mS} \mathrm{cm}^{-1}$ & $1068 \mu \mathrm{S} \mathrm{cm}^{-1}$ & $16 \mathrm{mS} \mathrm{cm}^{-1}$ & $726 \mu \mathrm{S} \mathrm{cm}^{-1}$ & $15.2 \mathrm{mS} \mathrm{cm}^{-1}$ & $344 \mu \mathrm{S} \mathrm{cm}^{-1}$ \\
\hline$B O D m g L^{-1}$ & 13187.5 & 1624.7 & 81.6 & 1033.9 & 47.3 & 400.3 & 0 \\
\hline$C O D m g L^{-1}$ & 54500 & 1000 & 59.5 & 2750 & 122.5 & 1172.5 & 0 \\
\hline$T S m g L^{-1}$ & 43559.8 & 3763.6 & 300 & 4114.2 & 0 & 2554.7 & 0 \\
\hline$F S m g L^{-1}$ & 11324 & 2431.4 & 300 & 3383.1 & 0 & 2077.7 & 0 \\
\hline$V S m g L^{-1}$ & 32235.8 & 1332.3 & 0 & 731.1 & 0 & 477 & 0 \\
\hline$C m g L^{-1}$ & 54034,5 & 2.400 & - & 2600 & 400 & 1440 & 620 \\
\hline$N$-total $m g L^{-1}$ & 1670.8 & 1598.8 & 49 & 1845.2 & 38,1 & 1933.8 & 27.8 \\
\hline$P m g L^{-1}$ & 415.7 & 16.7 & $<1.0$ & 56.7 & $<1.0$ & 39.1 & 4.0 \\
\hline$K m g L^{-1}$ & 1069.9 & 1213.2 & 14.9 & 1106.9 & 17.7 & 1305.5 & 20.5 \\
\hline Ca $m g L^{-1}$ & 229.9 & 49 & 13.8 & 30.9 & $<0.003$ & $<0.003$ & $<0.003$ \\
\hline$M g m g L^{-1}$ & 157.5 & 28 & $<0.0004$ & 31.5 & $<0.0004$ & 28 & $<0.0004$ \\
\hline$N a m g L^{-1}$ & 322.3 & 352.2 & 110.0 & 343.2 & 144.6 & 323.5 & 80.0 \\
\hline Cu $m g L^{-1}$ & 13.6 & 1 & $<0.004$ & 1.4 & $<0.004$ & 0.3 & $<0.004$ \\
\hline Fe mg $L^{-1}$ & 19.8 & 2.4 & $<0.005$ & 3.8 & 0.8 & 2 & $<0.005$ \\
\hline$Z n m g L^{-1}$ & 44.0 & 3.3 & 0.15 & 4.8 & 0.4 & 0.8 & $<0.001$ \\
\hline$M n m g L^{-1}$ & 7.0 & 0.1 & $<0.003$ & 1.3 & $<0.003$ & 0.1 & $<0.003$ \\
\hline
\end{tabular}

\subsection{Carbon Biodegradation of Swine Effluents}

The Figure 1 shows the accumulated $\mathrm{C}-\mathrm{CO}_{2}$ evolution along of 172 days, around six months, of biodegradation test conduction, in each application studied. For first application, equal to $33.3 \mathrm{~mm}$ of WB, there was EC values stabilization to 52 days and higher $\mathrm{CO}_{2}$ evolution was observed for Oxisol treatments (CS) (Figure 1). Similarlly, it was observed after last effluent application, equal to $33.3 \mathrm{~mm}$ of WB (R2 and R5) and WBD (R3 and R6), in that the EC values stabilized to 45 days, however, for this period, there was differences between treatments studied as a function of effluent and soil types.

Thus, after third application done to 72 days of test conduction, the differences observed between WB treatments and WBD treatments were higher for Ultisol treatments (SS) (R5 and R6) in comparison to Oxisol treamtments (CS) (R2 and R3) (Figure 1). This fact was attributed to formation of organominerals complexes in clayey soil (CS) that prevented the fast organic material degradation added by WB, reducing the differences observed in CS between treatments with use of WB and WBD (Lourenzi, 2014; Bertoncini et al., 2008). 
For the second application in which it was used lower amount of effluent, equal to $8.3 \mathrm{~mm}$ of WB (R2 and R5) and WBD (R3 and R6), the EC values estabilized to 72 days (Figure 1), a slower process compared to organic material degradation added by higher amounts of effluents. Probably, in this period, there was the degradation of remaining organic material from previous application, which had recalcitrant characteristics. And, in turn, the lower amount of organic material easily degradable was degraded shortly after effluents applications, as described by Fernandes et al. (2011) in which the higher $\mathrm{CO}_{2}$ release occurred two days after the application of an anaerobic swine wastewater in an Oxisol, in study conducted for 26 days.

So, only the higher amount of effluent applied, wich represent a frequent irrigation of WB, could cause the fast degradation of organic material added (Figure 1). Considering that the WB and WBD presented low $\mathrm{C} / \mathrm{N}$ ratio and higher nitrogen content (Table 1), the organic material added by second effluent amount studied wasn't able to activate the decomposing microorganisms, which had reduced activity throughout 72 days of evaluations. Since the $\mathrm{C} / \mathrm{N}$ relation of organic material added to soil has an influence on degradation of this material by microorganisms (Aita, 1997).

It was expected that the addition of effluent with low $\mathrm{C} / \mathrm{N}$ ratio would promote the priming effect, i.e., the consumption of native organic matter from the soil, in order to supply energy the decomposing microorganisms. This fact probably did not occur due to the high load of organic material added to the soils in the first application.

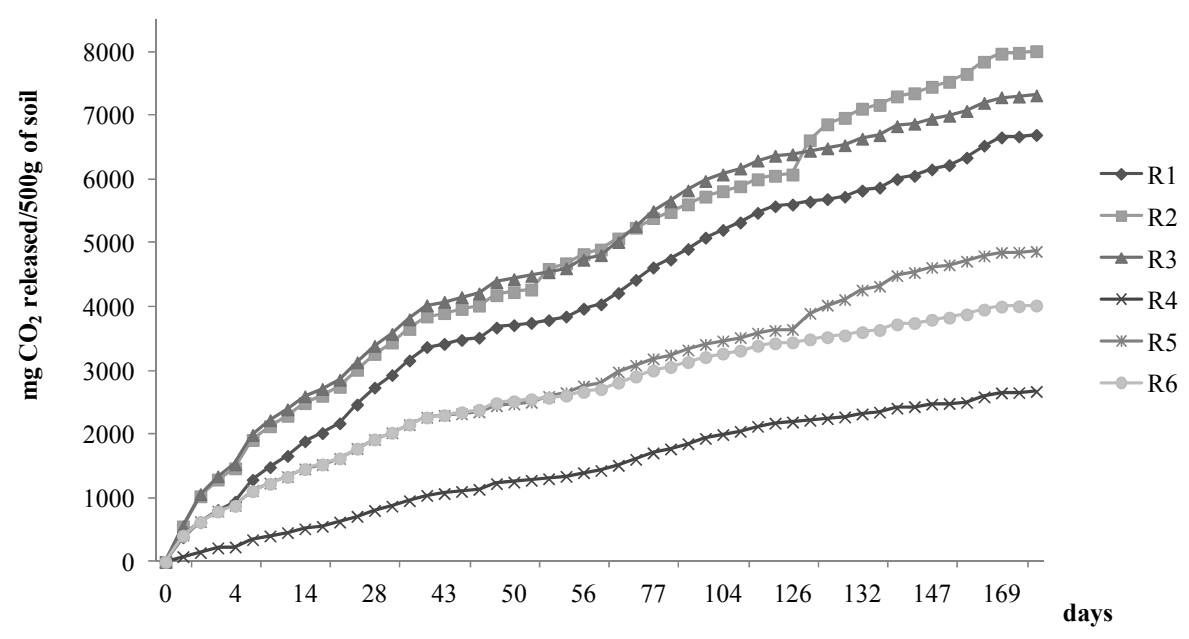

Figure 1. C- $\mathrm{CO}_{2}$ released after succesive applications of treated swine wastewater (WB) and diluted swine wastewater (WBD) (1:50, v:v), in a clayey Oxisol (CS) and Ultisol (SS) with medium-sandy texture. R1 - CS control; R2 - CS treated with WB; R3 - CS treated with WBD; R4 - SS control; R5 - SS treated with WB; R6 SS treated with WBD

Adjusting the $\mathrm{C}-\mathrm{CO}_{2}$ results obtained in respirometry test to first-order kinetics model, it was observed that correlation coefficient ranged from of 0.92 and 0.99 , for all applications studied (Tables 2, 3 and 4), soon, there was appropriate adjustment of data to mathematic model studied (Saviozzi et al., 1997; Reis \& Rodella, 2002; Teles et al., 2009).

In Table 2 are presented the variable values obtained 51 days after first effluent applications, and higher values of $\mathrm{CO}_{2}$ released were obtained for R2 and R3, which were statistically equal, followed by R1, R5, R6 and R4. Thus, the changes in $\mathrm{C}-\mathrm{CO}_{2}$ released were due to soils characteristics. Since the Oxisol (CS) presented higher carbon content (1.8\%) in comparison to Ultisol (SS) $(0.14 \%)$ (Table 1), and thus, higher amount of $\mathrm{CO}_{2}$ were released from Oxisol treatments (R1, R2 and R3) compared to Ultisol treatments, due to degradation of higher organic material amount.

Too, other studies found effects in $\mathrm{CO}_{2}$ releasing from soils with higher clay content and carbon, as it performed by Hamarashid, Othman, and Hussain (2010) comparing fine textured soils (clayey soils) to coarse textured soils (sandy soils) incubated with vegetable waste for seven weeks. And study performed by Martines, Andrade, and Cardoso (2006) comparing Oxisol to Entisol amended with tannery sludge doses ( 3 to $\left.6 \mathrm{t} \mathrm{ha}^{-1}\right)$ and incubated for 105 days. All studies observed higher $\mathrm{CO}_{2}$ releasing from clayer soils due to higher carbon content present in 
these soils compared to sandy soils, this fact occurred due to interactions between argilominerals and the native organic matter of clayey soils preventing the reduction in carbon content of these soils (Bayer et al., 2002; Bertoncini et al., 2008).

However, Maluf et al. (2015) observed no effect of soil texture about $\mathrm{CO}_{2}$ evolution, in study that evaluated the vegetable waste degradation in soils with textures simulated in laboratory from a Oxisol treated with different sand amounts; nevertheless, in this study the authors considered absence the effects of native soil organic matter about $\mathrm{CO}_{2}$ releasing, since, the $\mathrm{CO}_{2}$ results were described in net values.

Too, for this first WB application, the $C_{0}$ values were estimated, that is the amount of $\mathrm{CO}_{2}$ potentially released during test conduction time. As it was observed for $\mathrm{CO}_{2}$, the changes in $C_{0}$ values occured as function to different carbon contents of two soils studied. And, there was increasing in $C_{0}$ values of treatments with WB applications (R2, R3, R5 and R6). Besides this, for these treatments, the $C_{0}$ values were lower than $C$-released values, probabily, in this period (51 days) there was degradation of all organic material able to be depurate by both soils (CS and SS), as it was observed by Martines et al. (2006) after adjustment to first-order kinetics model of released $\mathrm{CO}_{2}$ values from soils with different textures treated with tannery sludge rates.

Table 2. First-order kinectics equation parameters estimated from adjust of dates of $\mathrm{C}-\mathrm{CO}_{2}$ released, and organic carbon degradation fractions obtained 51 days after the first application of treated swine wastewater $(33.3 \mathrm{~mm}$ of WB) in a clayey Oxisol (CS) and Ultisol (SS) with medium-sandy texture

\begin{tabular}{|c|c|c|c|c|c|c|}
\hline Treatments & $\mathrm{C}-\mathrm{CO}_{2}$ released & $C_{0}$ & $\mathbf{R}^{2}$ & $\mathbf{K}$ & $\mathbf{T}_{1 / 2}$ & C degraded \\
\hline & \multicolumn{3}{|c|}{------ mg/500 g of soil ------- } & --- day ${ }^{-1}$--- & --- day --- & ------- \% ------- \\
\hline $\mathrm{R} 1$ & $3725.3 \mathrm{~B}$ & $3915.9 \mathrm{~B}$ & 0.99 & $0.048 \mathrm{C}$ & $14.5 \mathrm{~B}$ & $11.3 \mathrm{D}$ \\
\hline $\mathrm{R} 2$ & $4421.0 \mathrm{~A}$ & $4200.6 \mathrm{~A}$ & 0.98 & $0.075 \mathrm{AB}$ & $9.3 \mathrm{C}$ & $46.2 \mathrm{BC}$ \\
\hline $\mathrm{R} 3$ & $4484.1 \mathrm{~A}$ & $4272.1 \mathrm{~A}$ & 0.98 & $0.073 \mathrm{~B}$ & $9.5 \mathrm{C}$ & $48.9 \mathrm{~B}$ \\
\hline R4 & $1265.0 \mathrm{D}$ & $1536.8 \mathrm{D}$ & 0.99 & $0.029 \mathrm{D}$ & $23.6 \mathrm{~A}$ & $46.0 \mathrm{C}$ \\
\hline R5 & $2540.2 \mathrm{C}$ & $2401.0 \mathrm{C}$ & 0.97 & $0.078 \mathrm{~A}$ & $9.0 \mathrm{C}$ & $108.7 \mathrm{~A}$ \\
\hline R6 & $2556.6 \mathrm{C}$ & $2426.0 \mathrm{C}$ & 0.98 & $0.073 \mathrm{~B}$ & $9.6 \mathrm{C}$ & $110.1 \mathrm{~A}$ \\
\hline $\mathrm{CV} \%$ & 0.8 & 1.3 & & 2.4 & 5.5 & 1.6 \\
\hline
\end{tabular}

Note. R1 - CS control; R2 - CS treated with WB; R3 - CS treated with WBD; R4 - SS control; R5 - SS treated with WB; R6 - SS treated with WBD. In this first evaluation only the WB was applied in R2, R3, R5 and R6. Means followed by the same capital letters in the vertical for the treatments studied, do not differ (Tukey $5 \%$ ).

It was observed that the controls (R1 and R4) differed significantly from all other treatments for the organic matter degradation velocity values $(k)$ and for half-life time values $\left(T_{1 / 2}\right)$, and the treatments R2, R3, R5 and R6 did not differ statistically between them (Table 2). Soon, for this first application using WB application, there were no effects of soil texture about degradation velocity and residence time of organic material.

It was also observed that more than half of $C_{0}$ was released in $\mathrm{C}_{-} \mathrm{CO}_{2}$ form after ten days of test conduction, showing that there was a fast mineralization phase followed by a slow mineralization phase and stabilization of $\mathrm{C}-\mathrm{CO}_{2}$ released flow. Studies performed by Luz (2007) with swine waste and by Martines et al. (2006) with tannery sludge found fast organic matter degradation ( 6 and 10 days, respectively). It is emphasized that these wastes too presented low $\mathrm{C} / \mathrm{N}$ ratio and high content of nitrogen in mineral form.

Unlike what was expected, the clayey soil control (R1) presented higher degradation velocity $\left(k=0.048\right.$ day $\left.^{-1}\right)$ and lower half-life time $\left(T_{1 / 2}=14.5\right.$ days) of soil native organic matter in comparison to values obtained for sandy soil that presented (R4) values equal to 0.029 day $^{-1}$ e 23.6 days, respectively. This can be explained by the fact that the Oxisol was in fallow, kept only with grass on its surface, while that the Ultisol had been cultivated with sugarcane for many years, being in constant process of mineralization of its native organic matter. Deionized water was added in flasks of Oxisol control, promoted start in the process of decomposition of native organic matter. Probably, also, the Ultisol presented a greater amount of organic matter more recalcitrant to decomposition process. Liu et al. (2003) compared soils cultivated and no cultivated soils, and they found higher organic matter content in no cultivated soils when compared to cultivated soils, besides this, they observed significative reduction in organic matter on the uncultivated soil surface after the first years of cultivation.

Despite this, it was observed that the the degradation rates was equal to 46.2 (R2) and $48.9 \%$ (R3) for amended Oxisol (CS), when compared to same treatments of Ultisol (SS) whit degradation rates equal to 108.7 and 
$110.1 \%$ for R5 and R6, respectively. For sandy soil treatments were observed degradation of organic matter native, process known as priming effect, and it is characterized by increase in decompositor microorganism population in function of increase in energy, and consequent degradation of all organic material from the residue and a part of the native organic matter (Fontaine et al., 2003), and this can cause depletion of soil fertility. The same effect was not observed for clayey soil treatments due to probable formation of stable links between the organic material and the clay minerals (Bertoncini et al., 2008; Inda Junior et al., 2007).

After the second application of $8.3 \mathrm{~mm}$ of WB (R2 and R5) and WBD (R3 and R6), the changes reflected the small addition of organic matter by effluent amount studied. There was EC stabilization to 72 days, after this second application, the data obtained in this period was adjusted to first-order kinetics model (Table 3). Treatment with WBD addition (R3) presented higher evolution of $\mathrm{C}-\mathrm{CO}_{2}$ in comparison to other treatments, including in relation to clayey soil amended with WB (R2).

Setia et al. (2011) found reduction in $\mathrm{C}-\mathrm{CO}_{2}$ released in function of increase in salinity of soils with different textures, due to the reduction in the population of decomposing microorganisms. It could be argued that the lower $\mathrm{CO}_{2}$ released values observed for $\mathrm{R} 2$ (WB) in comparison to R3 (WBD) could be due to the high values of EC and Na content present in WB (Table 1). However, for sandy soil was not observed reductions in C-released for treatment irrigated with WB (R5) when compared to treatment irrigated with WBD (R6).

Soon, there was fast degradation of small amount of easily degradable organic material added to R2, since, this treatment presented higher degradation velocity $(k)$ and lower half-life time $\left(T_{1 / 2}\right)$ compared to other treatments. In confront, R3 presented lower $k$ values and higher $T_{1 / 2}$ values, despite of this treatment had presented higher values of $C$-released, reflecting the degradation process of a more recalcitrant organic material remaining of previous application of WB in treatments R2, R3, R5, and R6.

Table 3. First-order kinectics equation parameters estimated from adjust of dates of $\mathrm{C}-\mathrm{CO}_{2}$ released, and organic carbon degradation fractions obtained 72 days after the second application of treated swine wastewater and diluted swine wastewaster (8.3 $\mathrm{mm}$ of WB and WBD) in a clayey Oxisol (CS) and Ultisol (SS) with medium-sandy texture

\begin{tabular}{|c|c|c|c|c|c|c|}
\hline Treatments & $\mathrm{C}-\mathrm{CO}_{2}$ released & $C_{0}$ & $\mathbf{R}^{2}$ & $\mathbf{k}$ & $T_{1 / 2}$ & $\mathrm{C}$ degraded \\
\hline & \multicolumn{3}{|c|}{-------- mg/500 g of soil -------- } & --- day ${ }^{-1}$--- & --- day --- & -------- \% -------- \\
\hline $\mathrm{R} 1$ & $1860.0 \mathrm{~B}$ & $2825.3 \mathrm{~A}$ & 0.99 & $0.014 \mathrm{D}$ & $48.9 \mathrm{~A}$ & $16.9 \mathrm{E}$ \\
\hline $\mathrm{R} 2$ & $1802.3 \mathrm{~B}$ & $1744.0 \mathrm{C}$ & 0.97 & $0.047 \mathrm{~A}$ & $14.9 \mathrm{D}$ & $35.6 \mathrm{D}$ \\
\hline R3 & $1944.8 \mathrm{~A}$ & $2625.7 \mathrm{~B}$ & 0.99 & $0.019 \mathrm{C}$ & $36.3 \mathrm{~B}$ & $55.6 \mathrm{C}$ \\
\hline $\mathrm{R} 4$ & $913.1 \mathrm{D}$ & $1365.3 \mathrm{D}$ & 0.99 & $0.015 \mathrm{CD}$ & $48.0 \mathrm{~A}$ & $79.2 \mathrm{~B}$ \\
\hline R5 & $1155.6 \mathrm{C}$ & $1211.3 \mathrm{E}$ & 0.99 & $0.034 \mathrm{~B}$ & $20.8 \mathrm{C}$ & $101.9 \mathrm{~A}$ \\
\hline R6 & 896.7 D & $1181.4 \mathrm{E}$ & 0.99 & $0.019 \mathrm{C}$ & $37.7 \mathrm{~B}$ & $104.4 \mathrm{~A}$ \\
\hline$C V \%$ & 2.1 & 2.8 & & 6.5 & 4.7 & 1.7 \\
\hline
\end{tabular}

Note. R1 - CS control; R2 - CS treated with WB; R3 - CS treated with WBD; R4 - SS control; R5 - SS treated with WB; R6 - SS treated with WBD. Treatments mean followed by the same capital letters, vertically, do not differ from each other (Tukey 5\%).

The $C_{0}$ values estimated for $\mathrm{R} 2$ showed that there was degradation of all organic material able to be depurated by soil, along of 72 days, since, the $C_{0}$ values were lower than $\mathrm{C}-\mathrm{CO}_{2}$ released values quantified by respirometry test, as it was observed for the first evaluation. The other treatments (R1, R3, R4, R5 and R6) presented $C_{0}$ values higher than $\mathrm{C}-\mathrm{CO}_{2}$ released values due to presence of biodegradable organic material.

As it was observed for Oxisol (clayey soil), the treatment of Ultisol + WB (sandy soil) (R5) presented lower half-life time $\left(T_{1 / 2}\right)$ and higher degradation velocity $(k)$ when compared to other Ultisol treatments (R3 and R6), probably, this fact occurred due to increase in microrganism activity after fresh organic material addition. Already both WBD amended soils presented no differences between them for the parameters degradation velocity and half-life time, since that the observed effect was due to the increase in soil water content and not to increase in organic matter.

So, after the second application, the values obtained for studied variables showed that the low organic material added caused no changes in the degradation process. Since, the degradation fraction obtained for R2 (Table 3) reduced in relation to the degradation fraction obtained after the first WB application (Table 2), showing absence 
of degradation of new content of organic matter added, the same was observed for treatments R5 and R6 of sandy soil. However for R3, it was observed increase in degradation fraction, probably, due to remaining organic material degradation of previous WB application, as it was discussed before.

After the third application, equal to $33.3 \mathrm{~mm}$ both WB and WBD, it was observed higher released of $\mathrm{C}-\mathrm{CO}_{2}$ in treatments irrigated with WB for both soils studied (R2 and R5) (Table 4), due to increase in organic matter added. However, there was higher evolution in $\mathrm{C}-\mathrm{CO}_{2}$ for Oxisol treatment (R2) in function of its higher $\mathrm{C}$ content in comparison to Ultisol, as it was related in studies performed with vegetable wastes by Hamarashid et al. (2010) and with tannery sludge by Martines et al. (2006). Already, the treatments irrigated with WBD presented lower $\mathrm{C}-\mathrm{CO}_{2}$ released values compared to treatments irrigated with $\mathrm{WB}$, which presented values equal or lower than control treatment of each soil (R1 and R4), since the organic matter reserve in these soils treated with diluted effluent was lower than that observed in the control soils after the first and second applications. Similar results were obtained for $C_{0}$ after adjust done to degradation kinetics equation, treatments with use of WB (R2 and R5) presented higher values in comparison to treatments with use of WBD (R3 and R6).

Table 4. First-order kinectics equation parameters estimated from adjust of dates of $\mathrm{C}-\mathrm{CO}_{2}$ released, and organic carbon degradation fractions obtained 45 days after the third application of treated swine wastewater and diluted swine wastewater (33.3 mm of WB and WBD) in a clayey Oxisol (CS) and Ultisol (SS) with medium-sandy texture

\begin{tabular}{|c|c|c|c|c|c|c|}
\hline Treatments & $\mathrm{C}-\mathrm{CO}_{2}$ released & $C_{0}$ & $\mathbf{R}^{2}$ & $\mathbf{k}$ & $T_{1 / 2}$ & C degraded \\
\hline & \multicolumn{3}{|c|}{ - } & --- day ${ }^{-1}$--- & --- day --- & ----- \% ----- \\
\hline R1 & $1088.3 \mathrm{C}$ & $2726.8 \mathrm{~A}$ & 0.99 & $0.011 \mathrm{E}$ & $61.8 \mathrm{~A}$ & $20.2 \mathrm{E}$ \\
\hline R2 & $1927.6 \mathrm{~A}$ & $1673.5 \mathrm{~B}$ & 0.92 & $0.157 \mathrm{~A}$ & $4.4 \mathrm{D}$ & $53.5 \mathrm{C}$ \\
\hline R3 & $900.7 \mathrm{D}$ & $1147.9 \mathrm{C}$ & 0.99 & $0.032 \mathrm{CD}$ & $21.7 \mathrm{C}$ & $35.2 \mathrm{D}$ \\
\hline R4 & $528.3 \mathrm{E}$ & $924.7 \mathrm{CD}$ & 0.99 & $0.018 \mathrm{DE}$ & $38.4 \mathrm{~B}$ & $98.4 \mathrm{~A}$ \\
\hline R5 & $1188.8 \mathrm{~B}$ & $1126.6 \mathrm{C}$ & 0.98 & $0.110 \mathrm{~B}$ & $6.4 \mathrm{D}$ & $99.3 \mathrm{~A}$ \\
\hline R6 & $579.8 \mathrm{E}$ & $698.3 \mathrm{D}$ & 0.99 & $0.037 \mathrm{C}$ & $18.8 \mathrm{C}$ & $87.1 \mathrm{~B}$ \\
\hline $\mathrm{CV} \%$ & 3.0 & 9.1 & & 9.1 & 15.6 & 2.7 \\
\hline
\end{tabular}

Note. R1 - CS control; R2 - CS treated with WB; R3 - CS treated with WBD; R4 - SS control; R5 - SS treated with WB; R6 - SS treated with WBD. Treatments mean followed by the same capital letters, vertically, do not differ from each other (Tukey 5\%).

According to Fernandes et al. (2011) the high $\mathrm{N}^{-\mathrm{NH}_{4}}{ }^{+}$content present in swine wastewater cause singnificative increase in microbian biomass present in soil, biodegrading the easily degradable carbon, however, this fact associate to increase in recalcitrant organic material provides the soil native organic matter degradation. This effect was observed along of this study, after the first application of WB, there was increase in $\mathrm{C}-\mathrm{CO}_{2}$ released followed by reduction of these values after second application of WB and WBD, showing reduction in microorganism activity. After the third application, this reduction was more evident in treatments with WBD use, which presented lower microbiologic activity than control of each soil, showing possible soil native organic matter depletion.

For this third evaluation, there was EC values stabilization in 45 days, less time than for the first and second applications, showing that there was fast degradation of organic matter when successive application of WB were done. This fact was confirmed by degradation velocity values $(k)$ obtained for treatments with WB use (R2 and R5), which were equals to 0.157 and $0.110 \mathrm{day}^{-1}$, respectively. These $k$ values were higher than values obtained for treatments with WBD use (R3 and R6), which were equals to 0.032 and 0.037 day $^{-1}$, respectively (Table 4). Consequently, the half-life time values $\left(T_{1 / 2}\right)$ obtained for R2 and R5 were lower than values obtained for other treatments, and these values were equals statistically (4.4 and 6.4 days, respectively). The treatments irrigated with WBD (R3 and R6) too presented $T_{1 / 2}$ values equals statistically (21.7 and 18.8 days, respectively). The $T_{1 / 2}$ values obtained for the third application of WB (Table 4) were lower compared to $T_{1 / 2}$ values obtained after the first application of WB (Table 2), despite of both applications had been done with the same amount of WB.

Although, there was no observed effect of soil texture about the half-life time of organic matter in the soil, it was observed effect about degradation fraction values after the third application of WB (Table 4). Since that higher degradation fraction values were obtained for Ultisol treatments ( $\mathrm{R} 5=99.3 \%$ and $\mathrm{R} 6=87.1 \%$ ) compared to 
Oxisol treatments $(\mathrm{R} 2=58.5$ and $\mathrm{R} 3=35.2 \%)$, probably due to interaction of organic matter with clay minerals, preventing the organic matter degradation applied to Oxisol (Bertoncini et al., 2008; Inda Junior et al., 2007).

The degradation fractions were obtained considering the total of organic material applied by the three amounts of effluents studied. Thus, after it had been observed the priming effect in occasion of the first evaluation, there were reductions in degradation fraction values along of respiromety test for R3, R5 and R6 after the second and third evaluation, evidencing possible accumulation of organic material. Therefore, studies about biodegradable of organic material added throughout successive applications of treated swine wastewater should be performed, since that the priming effect observed is not desired in soils about tropical conditions, which already present low organic matter contents.

\section{Conclusion}

Soil texture was a predominant factor in the organic matter decomposition after sucessive applications of swine wasterwater tratead in biodigestor. It was evident the formation of organomineral complex between organic matter and clay minerals in more clayey Oxisol when amended with diluted effluent. Priming effect was observed in sandy soil amended with swine wastewater causing the depletion of Ultisol native organic matter, effect is not desired for soils with low organic matter content, as such soils under tropical conditions. However, the WB use in fine textured soils, as Oxisol, can provide a real increase in its organic matter pool, since the low fractions of degradation were obtained for treatments of this soil.

Sucessive application of diluted effluent in both soils caused the degradation of recalcitrant organic matter remaining of previous application of more concentrated swine wastewater. In last two applications, the WBD use, which presented low organic matter content, caused the degradation of recalcitrant organic matter remaining of previous application of WB.

Increase in activity of microrganisms occurred when higher amount of WB was added in soils decomposing more than half of organic matter between 4 and 10 days of incubation, thereafter there was reduction in microorganism activity until stabilization process that occurred between 45 and 51 days.

Therefore, the organic matter present in the swine wastewaster treated in biodigestor presented high velocity and fraction of degradation, being reduced only in Oxisol with clayey texture. Thus, the respirometry test evidenced the importance of the evaluation of soil depuration capacity before agricultural use of organic wastes, in order that there is no depletion of the organic matter native of these soils, and to avoid unbalance in its fertility.

\section{References}

Agne, S. A. A., \& Klein, V. A. (2014). Organic matter and physical attributes of an Oxisol after swine waste application in perennial pastures. Revista Brasileira de Engenharia Agrícola e Ambiental, 18, 720-726. https://doi.org/10.1590/S1415-43662014000700008

Aita, C. (1997). Nitrogen dynamic in soil during decomposition of plants: Effects about disponibility of nitrogen for succession culture. In M. R. Fries \& R. S. D. Dalmolin (Eds.), Update on fertilization and liming reccomendation: Emphasis on no till (pp. 76-111). Santa Maria, RS: Pallotti.

Amaral, A. C., Kunz, A., \& Steinmetz, R. L. R. (2014). Zinc and copper distribution in swine wastewater treated by anaerobic digestion. Journal of Environment Management, 141, 132-137. https://doi.org/10.1016/ j.jenvman.2014.03.021

Bayer, C., Martin-Neto, L., Mielniczuk, J., Saab, S. C., Milori, D., \& Bagnato, V. S. (2002). Tillage and cropping system effects on soil humic acid characteristics as determined by electron spin resonance and fluorescence spectroscopies. Geoderma, 105, 81-92. https://doi.org/10.1016/S0016-7061(01)00093-3

Bertoncini, E. I. (2016). São Paulo’s Agency develops pilot model for reuse of swine waste. Brasília, DF: MAPA. Retrieved from http:/www.agricultura.gov.br/arq_editor/Boletim\%20Informativo\%2052.pdf

Bertoncini, E. I., D’Orazio, V., Senesi, N., \& Mattiazzo, M. E. (2008). Effects of sewage sludge amendment on the properties of two Brazilians Oxisols and their humic acids. Bioresource Technology, 99, 4972-4979. https://doi.org/10.1016/j.biortech.2007.09.024

Brazil. (1976). Decreto N. 8.468. Approve the regulament of Low n. 997, of May 31 of 1976, about prevention and control of pollution of environment. São Paulo, SP: Diário Oficial do Estado de São Paulo.

Ceretta, C. A., Girotto, E., Lourenzi, C. R., Trentin, G., Vieira, R. C. B., \& Burnetto, G. (2010). Nutrient transfer by runoff under no tillage in a soil treated with successive applications of pig slurry. Agriculture, Ecosystems and Environment, 139, 689-699. https://doi.org/10.1016/j.agee.2010.10.016 
Dinel, H., \& Gregorich, E. G. (1995). Structural stability status as affected by long-term continuous maize and bluegrass sod treatments. Biological Agriculture \& Horticulture, 12, 237-252. https://doi.org/10.1080/ 01448765.1995.9754744

Duda, R. M., \& Oliveira, R. A. (2011). Treatment of swine wastewater in UASB reactor and anaerobic filter in series followed of trickling filter. Engenaharia Sanitária Ambiental, 16, 91-100. https://doi.org/10.1590/ S1413-41522011000100013

Eaton, A. D., Leonore, S., Clesceri, E. W. R., \& Arnold, E. A. (2005). Standard Methods for the Examination of Water and Wastewater. Washington, DC: American Public Health Association, American Water Works Association \& Water Environment Federation.

Environmental Company of São Paulo State. (1999). Norm P 4.230 - Criteria for application of biosolids in agricultural areas: Criteria for design and operation. São Paulo, SP: Environmental Company of São Paulo State.

Fernandes, A. H. B. M., Cardoso, M. A., Souza, R. A. C., Fernandes, F. A., Soares, M. T. C., Crispim, S. M. A., ... Lisita, F. O. (2011). Nitrification and mineralization of carbon in soils treated with swine waste biodigested. Corumbá, MS: Brazilian Agricultural Research Corporation.

Fontaine, S., Mariotti, A., \& Abbadie, L. (2003). The priming effect of organic matter: A question of microbial competition? Soil Biology \& Biochemistry, 35, 837-843. https://doi.org/10.1016/S0038-0717(03)00123-8

Hamarashid, N. H., Othman, M. A., \& Hussain, M. A. H. (2010). Effects of soil texture on chemical compositions, microbial populations and carbon mineralization in soil. The Egyptian Journal of Experimental Biology (Botany), 6, 59-64.

Inda Junior, A. V., Bayer, C., Conceição, P. C., Boeni, M., Salton, J. C., \& Tonin, A. T. (2007). Selected soil-variables related to the stability of organo-minerals complexes in tropical and subtropical Brazilian soils. Ciência Rural, 37(5), 1301-1307.

Latham, J. L. (1974). Elementary reaction kinetics. São Paulo, SP: E. Blücher.

Liu, X. B., Han, X. Z., Herbert, S. J., \& Xing, B. (2003). Dynamics of soil organic carbon under different agricultural management system in the black soil of China. Communications in Soil Science and Plant Analysis, 34, 973-984. https://doi.org/10.1081/CSS-120019103

Lourenzi, C. R. (2014). Swine manure: Crops production, effects on organic matter and forms phosphorus transfer (Doctoral dissertation, Federal University of Santa Maria, Santa Maria, Brazil). Retrieved from http://w3.ufsm.br/ppgcs/images/Teses/CLEDIMAR-ROGERIO-LORENZI-TESE.pdf

Luz, L. P. (2007). Carbon dynamic during decomposition of ${ }^{13} C$-labelled wheat straw and pig slurry (Master's thesis, Federal University of Santa Maria, Santa Maria, Brazil). Retrieved from http://cascavel.ufsm.br/ tede//tde_busca/arquivo.php?codArquivo $=1053$

Maluf, H. J. G. M., Soares, E. M. B., Silva, I. R., Neves, J. C. L., \& Silva, L. O. G. (2015). Crop residue decomposition and nutrient mineralization in soil with fifferent textures. Revista Brasileira de Ciência do Solo, 39, 1681-1689. https://doi.org/10.1590/01000683rbcs20140657

Martines, A. M., Andrade, C. A., \& Cardoso, E. J. B. N. (2006). Mineralization of the organic carbon in soils treated with tannery sludges. Pesquisa Agropecuária Brasileira, 41, 1149-1155. https://doi.org/10.1590/ S0100-204X2006000700011

Moral, R., Perez-Murcia, M. D., Perez-Espinosa, A., Moreno-Caselles, J., Paredes, C., \& Rufete, B. (2008). Salinity, organic content, micronutrients and heavy metals in pig slurries from South-eastern Spain. Waste Management, 28, 367-371. https://doi.org/10.1016/j.wasman.2007.01.009

Novaes, W. (2001). Dilemmas of agrarian development. Estudos Avançados, 15, 51-60. https://doi.org/10.1590/ S0103-40142001000300006

Pereira, E. R. (2006). Residual water quality in systems for production and treatment of swine manure and its re-utilization in agricultural environments (Doctoral dissertation, University of São Paulo, Brazil). Retrieved from http://www.teses.usp.br/teses/disponiveis/11/11143/tde-17042006-171916/pt-br.php

Reis, T. C., \& Rodella, A. A. (2002). Dynamics of organic matter degradation and $\mathrm{pH}$ variation of soil under different temperatures. Revista Brasileira de Ciência do Solo, 26, 610-626. 
Rodella, A. A., \& Saboya, L. V. (1999). Calibration for condutimetric determination of carbon dioxide. Soil Biology \& Biochemistry, 31, 2059-2060. https://doi.org/10.1016/S0038-0717(99)00046-2

Saviozzi, A., Levi-Minizi, R., Riffaldi, R., \& Vanni, G. (1997). Role of chemical constituents of wheat straw and pig slurry on their decomposition in soil. Biology and Fertility of Soils, 25, 401-406. https://doi.org/ $10.1007 / \mathrm{s} 003740050332$

Setia, R., Marschner, P., Baldock, J., Chittleborough, D., Smith, P., \& Smith, J. (2011). Salinity effects on carbon mineralization in soils of varying texture. Soil Biology \& Biochemistry, 43, 1908-1916. https://doi.org/10.1016/j.soilbio.2011.05.013

Soares, M. T. S., Galvani, F., Fernandes, A. H. B. M., Fernandes, F. A., Lisita, F. O., Lima, I. B. T. de, ... Rieger, K. L. (2010). Physical-chemical characterization of liquid effluents of suines dejections treated in biodigestor. Proceedings of the Symposium on Natural and Socio-Economic Resources of Pantanal, 5, 1-4. Retrieved from http://www.cpap.embrapa.br/agencia/simpan5

Takitane, I. C., Silva, T. N., \& Wilk, E. de O. (2003). Sustentabilidade, competitividade e gestão ambiental no sistema de gestão de suínos: Uma discussão interdisciplinar. Proceedings of the National Meeting of Ecological Economics, 5, 1-21. Retrieved from http://www.ecoeco.org.br/conteudo/publicacoes/encontros/ v_en/Mesa4/4.pdf

Teles, C. R., Munaro, C. J., \& Cassini, S. T. A. (2009). Modeling of aerobic decomposition of sewage sludge in soils of different textures. Revista Brasileira de Engenharia Agrícola e Ambiental, 13, 197-203. https://doi.org/10.1590/S1415-43662009000200014

United States Departament of Agronomy. (2006). Keys to soil taxonomy. Washington, DC: United States Departament of Agronomy, Natural Resources Conservation Service.

Venables, W. N., \& Smith, D. M. (2013). An introduction to $R$ - Notes on $R$ : A programming environment for data analysis and graphics. The $\mathrm{R}$ Foundation for Statistical Computing. Retrieved from http://www.r-project.org

Vivan, M., Kunz, A., Stolberg, J., Perdomo, C., \& Tchio, V. H. (2010). Efficiency of biodigester and stabilization pond interaction in removal of swine manure pollutants. Revista Brasileira de Engenharia Agrícola e Ambiental, 14, 320-325. https://doi.org/10.1590/S1415-43662010000300013

\section{Copyrights}

Copyright for this article is retained by the author(s), with first publication rights granted to the journal.

This is an open-access article distributed under the terms and conditions of the Creative Commons Attribution license (http://creativecommons.org/licenses/by/4.0/). 